\title{
Sistem Navigasi Robot Hexapod Menggunakan Behavior Dan Learning Vector Quantization
}

\author{
Rendyansyah ${ }^{1)}$, Kanda Januar Miraswan ${ }^{2)}$, Aditya P.P. Prasetyo ${ }^{3)}$, Kemahyanto Exaudi' ${ }^{4)}$, Bangun \\ Sudrajat $^{5)}$ dan Abdul Wahid Sempurna ${ }^{6)}$ \\ 1,5,6) Jurusan Sistem Komputer, Fakultas Ilmu Komputer, Universitas Sriwijaya, Indonesia \\ 2) Jurusan Teknik Informatika, Fakultas Ilmu Komputer, Universitas Sriwijaya, Indonesia \\ 3,4) Jurusan Teknik Komputer, Fakultas Ilmu Komputer, Universitas Sriwijaya, Indonesia \\ email: ${ }^{1)}$ rendyansyah@ilkom.unsri.ac.id, ${ }^{2}$ kandajm@ilkom.unsri.ac.id, ${ }^{3)}$ aditrecca@ gmail.com, \\ 4) kemahyanto@ilkom.unsri.ac.id
}

\begin{abstract}
Abstrak- Robot banyak digunakan dalam berbagai bidang pekerjaan, salah satunya seperti pada mobile robot jenis berkaki untuk navigasi di dalam lingkungan yang kompleks. Robot berkaki atau dikenal dengan robot hexapod merupakan robot yang meniru pola gerak makhluk hidup. Pada penelitian ini telah dirancang robot hexapod yang dilengkapi dengan lima buah sensor jarak ultrasonik untuk bernavigasi di dalam lingkungan. Adapun tujuan robot hexapod ini bernavigasi untuk aplikasi robot patroli yang bekerja di lingkungan yang sulit diprediksi. Sistem navigasi pada robot hexapod menggunakan metode behavior based dan Learning Vector Quantization (LVQ). Pada robot hexapod memliki lima behavior, diantaranya behavior bergerak maju, mengikuti dinding kiri, mengikuti dinding kanan, mengikuti jalur koridor dan menghindar halangan. Pada masing-masing behavior tersebut untuk bernavigasi menggunakan LVQ. Salah satu behavior akan diaktifkan jika robot menerima masukan (stimuli) nilai jarak tertentu dari sensor jarak. Percobaan dilakukan dalam arena dengan kondisi yang telah ditentukan. Pada percobaan pertama, posisi robot dalam kondisi tanpa ada halangan, dan aksi robot tersebut berjalan maju sampai mendeteksi dinding atau halangan, dan selanjutnya robot melakukan aksi manuver kiri atau kanan berdasarkan behavior yang aktif. Pada percobaan kedua, posisi robot berada pada jalur koridor dan bernavigasi mengikuti jalur koridor tersebut. Selanjutnya pada percobaan ketiga, robot berada dalam lingkungan kompleks dimana robot tersebut ditempatkan pada posisi yang berbeda-beda, dan robot dapat bernavigasi dengan baik tanpa menabrak objek atau dinding.
\end{abstract}

Kata Kunci: Behavior based, Learning Vector Quantization, Navigasi, Robot hexapod

\section{Pendahuluan}

Perkembangan robot yang sangat pesat menjadikan robot sangat berguna dalam aspek kehidupan. Salah satu kegunaan robot dalam bidang keamanan yaitu seperti mobile robot untuk inpeksi target yang dicurigai [1]. Pada umumnya mobile robot ada yang beroda dan ada yang berkaki. Pada mobile robot yang beroda sistem gerak menggunakan motor listrik DC dengan kendali kecepatan menggunakan Pulse Width Modulation (PWM), dan untuk steering berbasis perbandingan kecepatan roda kiri dan kanan [2], atau bahkan menggunakan sudut belok pada roda bagian depan [3]. Namun pada mobile robot jenis berkaki (robot hexapod) cenderung meniru pola gerak makhluk hidup, seperti labalaba [4]. Sistem gerak robot berkaki umumnya menggunakan motor servo atau stepper.

Penelitian tentang robot hexapod telah dilakukan oleh Wicaksono dkk [4] dengan menerapkan prilaku sebagai aksi pergerakan robot ketika mendapat stimuli dari lingkungan sekitarnya. Darwison dan Wahyudi [5] merancang robot hexapod untuk pemadam api menggunakan sistem cerdas logika fuzzy, dan robot bernavigasi dengan perubahan kecepatan yang halus. Disisi lain, Wahyudi dkk [6] juga merancang sistem navigasi robot menggunakan kendali Proportional-Derivative untuk pergerakan robot mengikuti dinding.

Pergerakan robot berkaki sama seperti pada robot beroda yaitu memiliki sistem navigasi untuk menjelajah area yang dituju. Navigasi merupakan teknik dalam mengontrol pergerakan robot secara otonom baik untuk robot beroda maupun berkaki. Sistem navigasi pada robot memiliki beberapa metode, salah satunya yaitu behavior based $[4,7]$. Metode berbasis behavior ini sebagai aksi ketika menjelajah keadaan lingkungan yang tak dikenal. Metode ini dapat digabungkan dengan metode kecerdasan buatan karena mempermudah dan menghasilkan respon yang baik $[7,8]$. Salah satu metode kecerdasan buatan dalam pengenalan pola yaitu Learning Vector Quantization (LVQ) $[9,10]$. Metode LVQ ini merupakan salah satu metode yang menerapkan proses belajar (learning), yang mana data masukan (respon sensor jarak) dan keluaran (pergerakan) untuk dilakukan pelatihan dan pengujian berbasis komputer.

Berdasarkan latar belakang ini penulis melakukan penelitian di bidang robot berkaki yaitu robot hexapod. Robot hexapod ini bertujuan untuk bernavigasi pada lingkungan indoor dengan menggunakan behavior based dan metode LVQ, dan sebagai langkah awal untuk aplikasi robot patroli. Penerapan metode LVQ ini bertujuan supaya robot memiliki respon cepat dalam pengambilan keputusan pada saat bernavigasi. Adapun motivasi penggunaan robot hexapod ini untuk diaplikasikan pada lingkungan dengan permukaan kasar. 


\section{Metodologi Peneltian}

\section{A. Robot hexapod}

Pada penelitian ini dirancang robot hexapod yang dilengkapi dengan lima buah sensor jarak ultrasonik HCSR04, mikro arduino, driver motor servo SSC-32, motor servo sebanyak 18 buah, dan rangkaian catu daya. Gambar 1 menunjukkan bentuk fisik robot hexapod. Gambar 2 merupakan skematik hardware pada robot hexapod. Robot hexapod ini memiliki 6 kaki dan masing-masing kaki terdiri dari 3 servo, sehingga total servo berjumlah 18 buah servo. Robot dirancang dengan ukuran tinggi $14.5 \mathrm{~cm}$, panjang dan lebar $20 \mathrm{~cm}$

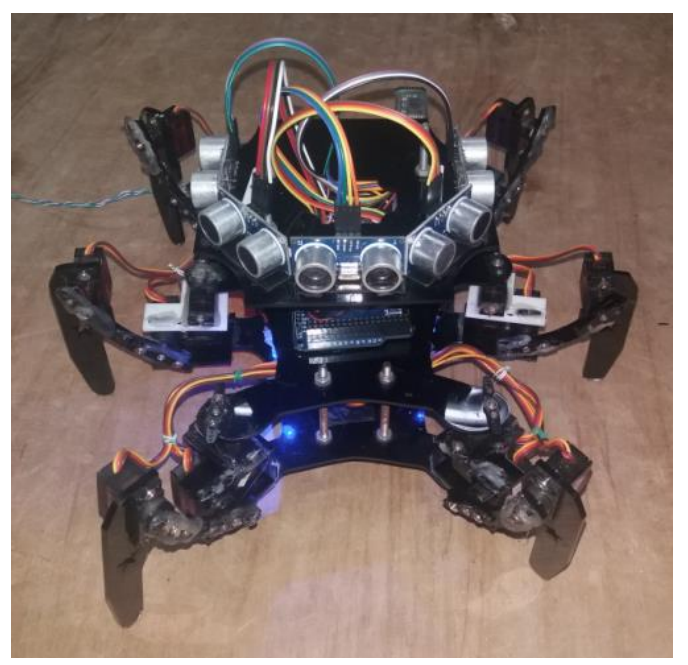

Gambar 1. Robot hexapod

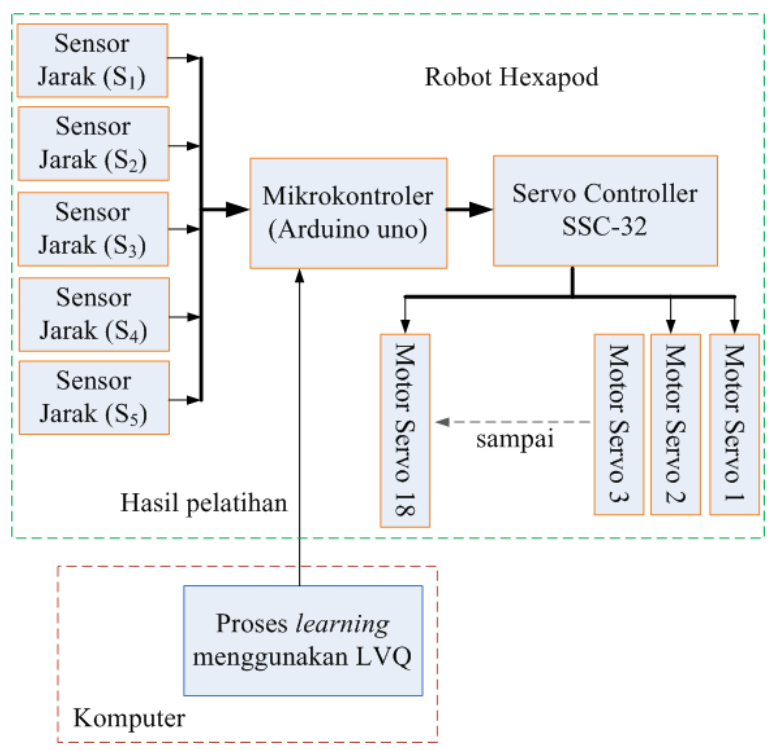

Gambar 2. Skematik hardware pada robot hexapod

Berdasarkan pada Gambar 1, robot dilengkapi dengan lima buah sensor jarak dan dipasang di bagian atas robot. Adapun penempatan sensor jarak tersebut membentuk setengah lingkaran yaitu dari sudut $0^{\circ}$ sampai $180^{\circ}$ dengan interval sudut $45^{\circ}$ seperti ditunjukkan pada Gambar 3 .
Fungsi sensor jarak untuk mendeteksi halangan objek ataupun dinding supaya robot dapat melakukan navigasi dalam menghindar halangan, mengikuti dinding ataupun jalur koridor berbasis behavior dan metode LVQ.

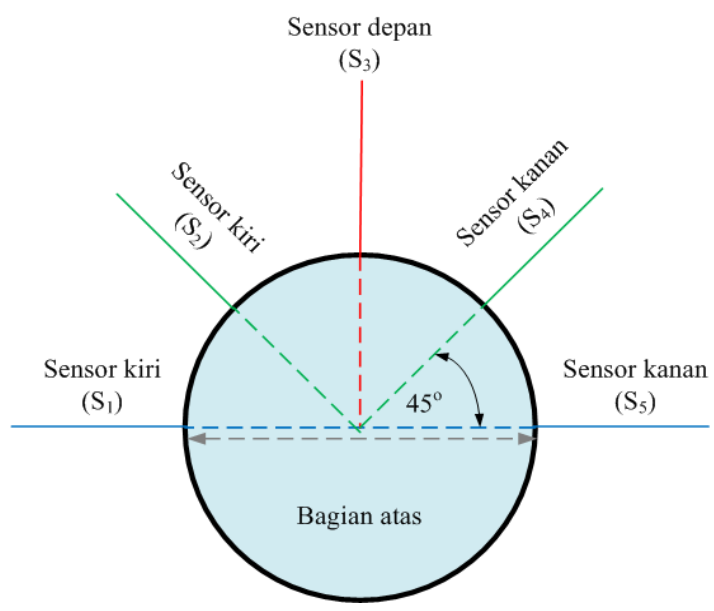

Gambar 3. Penempatan sensor jarak pada robot hexapod

\section{B. Sistem navigasi berbasis behavior}

Pada tahap ini dilakukan perancangan behavior untuk menentukan aksi pergerakan robot. Behavior yang dibentuk pada robot yaitu bergerak maju, mengikuti dinding kiri, mengikuti dinding kanan, mengikuti jalur koridor, dan mengindar halangan. Respon aksi ini karena adanya stimuli dari sensor jarak. Adapun urutan prioritas dalam mengaktifkan prilaku untuk navigasi pada robot yaitu:

1. Prioritas pertama (tertinggi); behavior menghindar halangan. Behavior ini aktif jika sensor depan $\left(\mathrm{S}_{3}\right)$ mendeteksi jarak halangan kurang dari $50 \mathrm{~cm}$.

2. Prioritas kedua; behavior mengikuti jalur koridor. Behavior ini aktif jika sensor kiri $\left(\mathrm{S}_{1}\right)$ dan kanan $\left(\mathrm{S}_{5}\right)$ mendeteksi jarak kurang dari $40 \mathrm{~cm}$, dan juga sensor kiri $\left(\mathrm{S}_{2}\right)$ dan kanan $\left(\mathrm{S}_{4}\right)$ dengan jarak kurang dari $50 \mathrm{~cm}$.

3. Prioritas ketiga; behavior mengikuti dinding kiri. Behavior ini aktif jika sensor kiri $\left(\mathrm{S}_{1}\right)$ deteksi kurang dari $40 \mathrm{~cm}$ dan sensor $\left(\mathrm{S}_{2}\right)$ deteksi kurang dari $50 \mathrm{~cm}$.

4. Prioritas keempat; behavior mengikuti dinding kanan. Behavior ini aktif jika sensor kanan $\left(\mathrm{S}_{5}\right)$ deteksi kurang dari $40 \mathrm{~cm}$ dan sensor $\left(\mathrm{S}_{4}\right)$ deteksi kurang dari $50 \mathrm{~cm}$.

5. Prioritas kelima (terendah); behavior bergerak maju. Behavior ini aktif jika semua sensor belum mendeteksi jarak dengan ambang batas tertentu terhadap objek atau dinding.

\section{Learning vector quantization}

Metode Learning Vector Quantization (disingkat LVQ) di-implementasikan ke dalam masing-masing prilaku robot. LVQ terdiri dari dua tahapan yaitu proses pelatihan dan pengujian. Pada tahap pelatihan data, program dirancang di dalam komputer dan menghasilkan bobot baru. Program pengujian juga dibuat di dalam komputer. Setelah selesai tahap program pelatihan maupun pengujian, maka program pelatihan di-embedd ke dalam mikrokontroller. Implementasi LVQ pada mikrokontroler robot hexapod 
supaya robot dapat bernavigasi secara otomatis.

Pada rancangan LVQ untuk proses pembelajaran perlu dirancang arsitektur LVQ yang terdiri dari input, layer hidden, dan output. Input berupa nilai jarak dari sensor jarak, dan output merupakan target pola yang telah ditentukan. Selama proses pembelajaran LVQ akan mencari nilai jarak antara suatu vektor input menuju bobot [10]. Adapun arsitektur LVQ untuk prilaku menghindar halangan, koridor, dan mengikuti dinding masing-masing seperti ditunjukkan Gambar 4. Di dalam penelitian ini variabel bobot yaitu $\mathrm{W}_{1}$, $\mathrm{W}_{2}$ dan $\mathrm{W}_{3}$.

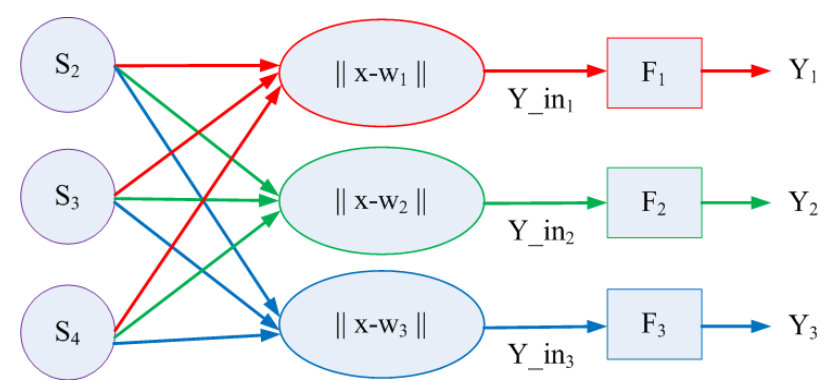

(a)

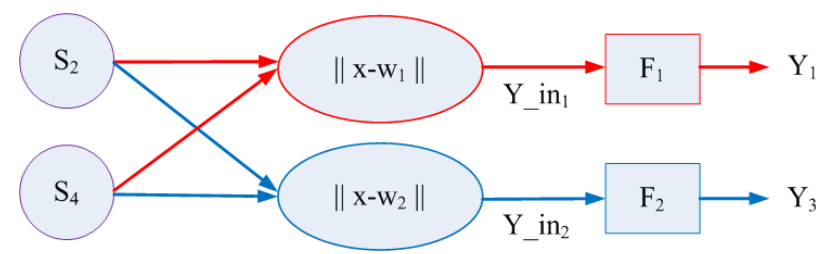

(b)

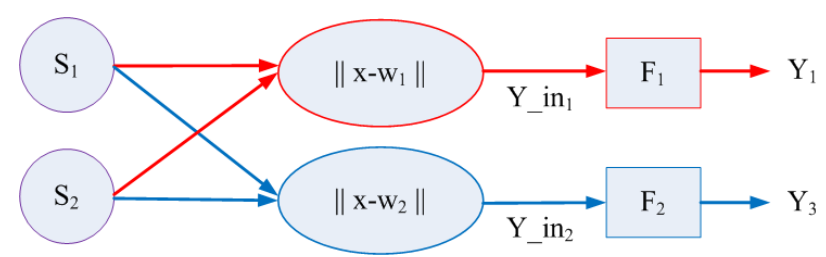

(c)

Gambar 4. Arsitektur LVQ untuk navigasi robot hexapod, (a) prilaku menghindar halangan, (b) prilaku mengikuti jalur koridor, dan (c) prilaku mengikuti dinding kiri dan untuk dinding kanan digunakan sensor kanan $\left(\mathrm{S}_{4}\right.$ dan $\left.\mathrm{S}_{5}\right)$

Setiap keluaran pada neuron menyatakan kelas, sehingga pola masukan dari sensor jarak dapat dikenali. Keluaran pada neuron $\mathrm{Y}_{1}$ merupakan aksi robot untuk belok kiri, neuron $\mathrm{Y}_{2}$ untuk pergerakan maju, dan $\mathrm{Y}_{3}$ untuk belok kanan. Arsitektur pada Gambar 4 terdiri dari algoritma pelatihan berbasis LVQ [10,11]:

1. Tetapkan:
a. nilai bobot $(\mathrm{w})$
b. Maksimum epoch (MaxEpoch)
c. Error minimum yang diinginkan $(\varepsilon)$
d. Learning rate $(\alpha)$

2. Masukkan:
a. Input : $\mathrm{x}(\mathrm{m}, \mathrm{n})$
b. Target : $T(1, n)$

3. Tetapkan kondisi awal:
a. Epoch $=0$
b. Tentukan nilai error

4. Kerjakan jika: (epoch $<$ MaxEpoch) atau $(\alpha>\varepsilon)$

a. Epoch $=$ epoch +1

b. Kerjakan untuk nilai $i=1$ sampai $n$

$>$ Tentukan $\mathrm{j}$ sedemikian hingga $\left\|\mathrm{x}-\mathrm{w}_{\mathrm{j}}\right\|$ minimum (sebut sebagai $\mathrm{c}_{\mathrm{j}}$ )

$>$ Perbaiki $\mathrm{w}_{\mathrm{j}}$ dengan ketentuan:

- Jika $\mathrm{T}=\mathrm{C}_{\mathrm{j}}$ maka :

$$
w_{j(\text { baru })}=w_{j(\text { lama })}+\alpha\left(x-w_{j(\text { lama })}\right)
$$

- Jika $\mathrm{T} \neq \mathrm{C}_{\mathrm{j}}$ maka :

$$
w_{j(\text { baru })}=w_{j(\text { lama })}-\alpha\left(x-w_{j(\text { lama })}\right)
$$

c. Perbarui atau kurangi nilai $\alpha$

Pada pengurangan nilai $\alpha$ dilakukan dengan cara $\alpha=\alpha-(\operatorname{dec} \alpha)$ atau $\alpha=\alpha^{*}(\operatorname{dec} \alpha)$.

\begin{tabular}{|c|c|c|c|c|}
\hline \multicolumn{3}{|c|}{ Sensor depan } & \multirow{2}{*}{ Target } & \multirow{2}{*}{ Keterangan } \\
\hline $\mathrm{S}_{2}$ & $\mathrm{~S}_{3}$ & $\mathrm{~S}_{4}$ & & \\
\hline 1 & 1 & 1 & \multirow{5}{*}{$Y_{1}$} & \multirow{5}{*}{ Belok kiri } \\
\hline 3 & 1 & 1 & & \\
\hline 3 & 2 & 1 & & \\
\hline 4 & 1 & 1 & & \\
\hline 4 & 2 & 1 & & \\
\hline 2 & 3 & 2 & \multirow{5}{*}{$Y_{2}$} & \multirow{5}{*}{ Maju } \\
\hline 2 & 3 & 3 & & \\
\hline 3 & 3 & 2 & & \\
\hline 3 & 3 & 3 & & \\
\hline 4 & 4 & 4 & & \\
\hline 1 & 1 & 3 & \multirow{4}{*}{$Y_{3}$} & \multirow{4}{*}{ Belok kanan } \\
\hline 1 & 2 & 3 & & \\
\hline 1 & 1 & 4 & & \\
\hline 1 & 2 & 4 & & \\
\hline
\end{tabular}

Tabel 1. Pola lingkungan untuk prilaku menghindar halangan

\begin{tabular}{|c|c|c|c|}
\hline \multicolumn{2}{|c|}{ Sensor } & \multirow{2}{*}{ Target } & \multirow{2}{*}{ Keterangan } \\
\hline $\mathrm{S}_{2}$ & $\mathrm{~S}_{4}$ & & \\
\hline 2 & 1 & \multirow{3}{*}{$\mathrm{Y}_{1}$} & \multirow{3}{*}{ Belok kiri } \\
\hline 3 & 1 & & \\
\hline 3 & 2 & & \\
\hline 1 & 2 & \multirow{3}{*}{$Y_{3}$} & \multirow{3}{*}{ Belok kanan } \\
\hline 1 & 3 & & \\
\hline 2 & 3 & & \\
\hline
\end{tabular}

Tabel 2. Pola untuk prilaku mengikuti jalur koridor

Setelah dilakukan tahap pelatihan maka diperoleh data bobot yang terbaru. Bobot-bobot ini digunakan untuk proses pengujian secara real time berbasis robot hexapod. Adapun 
data pelatihan merupakan pola dari keadaan lingkungan. Data pola ditentukan berdasarkan kuantisari dari nilai jarak yaitu; bagian sensor depan $\left(S_{2}, S_{3}\right.$, dan $\left.S_{4}\right)$ menjadi level kuantisasi pada Persamaan (1). Bagian sensor kiri $\left(S_{1}\right.$ dan $\left.S_{2}\right)$ dan kanan $\left(\mathrm{S}_{4}\right.$ dan $\mathrm{S}_{5}$ ) seperti pada Persamaan (2), dan bagian sensor untuk deteksi koridor $\left(\mathrm{S}_{2}\right.$ dan $\left.\mathrm{S}_{4}\right)$ seperti pada Persamaan (3). Pada Tabel 1 merupakan pola yang dibentuk untuk navigasi dalam behavior menghindar halangan. Tabel 2 menunjukkan pola untuk behavior mengikuti jalur koridor. Pada pola untuk behavior mengikuti dinding kiri maupun kanan masing-masing ditunjukkan pada Tabel 3 dan Tabel 4. Pengambilan data pola ini dilakukan secara offline dengan beberapa kemungkinan yang akan terjadi pada pergerakan robot hexapod di dalam lingkungan.

$$
\begin{aligned}
& S_{2,3,4}=\left\{\begin{array}{ccc}
1 & ; & 0 \mathrm{~cm} \leq S<30 \mathrm{~cm} \\
2 ; & 30 \mathrm{~cm} \leq S<45 \mathrm{~cm} \\
3 ; & 45 \mathrm{~cm} \leq S<60 \mathrm{~cm} \\
4 ; & 60 \mathrm{~cm} \leq S \leq 100 \mathrm{~cm}
\end{array}\right. \\
& S_{1,2 \operatorname{dan} 4,5}=\left\{\begin{array}{cc}
1 & ; \quad 0 \mathrm{~cm} \leq S<15 \mathrm{~cm} \\
2 & ; 15 \mathrm{~cm} \leq S<30 \mathrm{~cm} \\
3 & ; \quad 30 \mathrm{~cm} \leq S \leq 60 \mathrm{~cm}
\end{array}\right. \\
& S_{2,4}=\left\{\begin{array}{cc}
1 & ; \quad 0 \mathrm{~cm} \leq S<20 \mathrm{~cm} \\
2 & ; 20 \mathrm{~cm} \leq S<40 \mathrm{~cm} \\
3 & ; \quad 40 \mathrm{~cm} \leq S \leq 60 \mathrm{~cm}
\end{array}\right.
\end{aligned}
$$

\begin{tabular}{|c|c|c|c|}
\hline \multicolumn{2}{|c|}{ Sensor kiri } & \multirow{2}{*}{ Target } & \multirow{2}{*}{ Keterangan } \\
\hline $\mathrm{S}_{1}$ & $\mathrm{~S}_{2}$ & & \\
\hline 1 & 2 & \multirow{4}{*}{$Y_{1}$} & \multirow{4}{*}{ Belok kiri } \\
\hline 1 & 3 & & \\
\hline 2 & 3 & & \\
\hline 3 & 3 & & \\
\hline 1 & 1 & \multirow{5}{*}{$Y_{3}$} & \multirow{5}{*}{ Belok kanan } \\
\hline 2 & 1 & & \\
\hline 2 & 2 & & \\
\hline 3 & 1 & & \\
\hline 3 & 2 & & \\
\hline
\end{tabular}

Tabel 3. Pola untuk prilaku mengikuti dinding kiri

\section{Hasil dan Pembahasan}

Pada robot hexapod ini dilakukan pengujian untuk mengetahui respon pergerakan. Percobaan robot ditempatkan pada tiga kondisi lingkungan yaitu; lingkungan

\begin{tabular}{|c|c|c|c|}
\hline \multicolumn{2}{|c|}{ Sensor kanan } & \multirow{2}{*}{ Target } & \multirow{2}{*}{ Keterangan } \\
\hline $\mathrm{S}_{5}$ & $\mathrm{~S}_{4}$ & & \\
\hline 1 & 1 & \multirow{5}{*}{$Y_{1}$} & \multirow{5}{*}{ Belok kiri } \\
\hline 2 & 1 & & \\
\hline 2 & 2 & & \\
\hline 3 & 1 & & \\
\hline 3 & 2 & & \\
\hline 1 & 2 & \multirow{4}{*}{$Y_{3}$} & \multirow{4}{*}{ Belok kanan } \\
\hline 1 & 3 & & \\
\hline 2 & 3 & & \\
\hline 3 & 3 & & \\
\hline
\end{tabular}
bebas, lingkungan koridor dan lingkungan kompleks.
Tabel 4. Pola untuk prilaku mengikuti dinding kanan

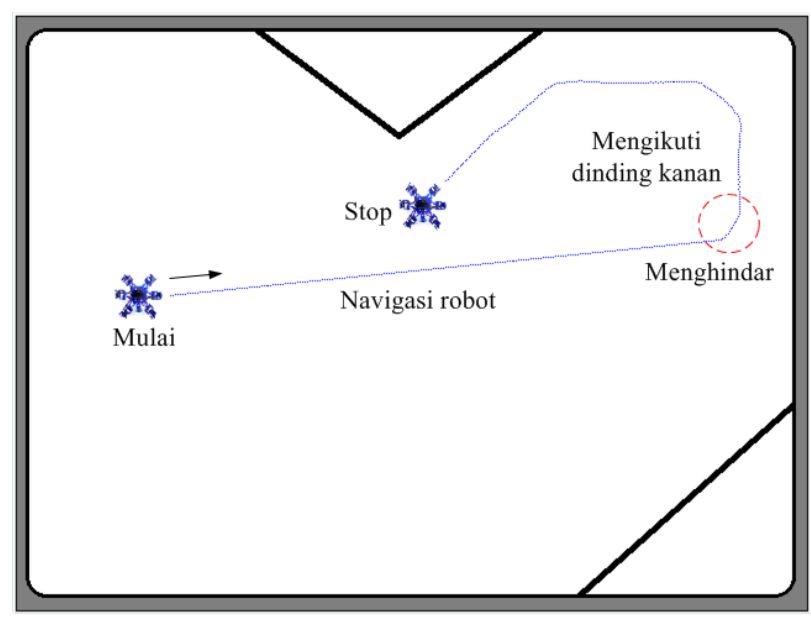

(a)

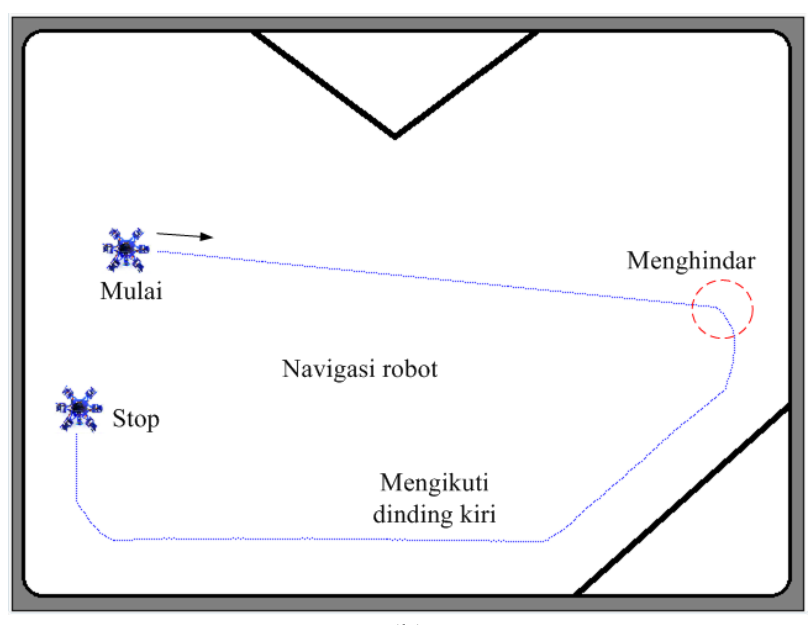

(b)

Gambar 5. Navigasi robot hexapod pada lingkungan bebas

A. Percobaan dalam lingkungan bebas

Pada percobaan ini robot hexapod ditempatkan pada posisi bebas dengan tujuan untuk megetahui respon pergerakan saat bernavigasi pada lingkungan bebas. Pada 
Gambar 5 menunjukkan navigasi robot hexapod pada lingkungan bebas. Pada saat dijalankan robot hexapod bergerak maju karena tidak ada halangan, dan kemudian mendeteksi adanya dinding sehingga robot bernavigasi menghindar halangan dengan belok ke kiri atau kanan berdasarkan stimuli dari sensor jarak bagian depan. Sensor jarak tersebut yaitu $S_{2}, S_{3}$ dan $S_{4}$ yang nilainya sudah dikuantisasi dan telah ditentukan aksi belok kiri atau kanan berdasarkan pola pada Tabel 1. Pada percobaan Gambar 5.a, robot bergerak maju sampai mendeteksi dinding, dan robot bernavigasi dengan behavior menghindar halangan yaitu belok kiri. Selanjutnya robot bernavigasi mengikuti dinding kanan dikarenakan sensor bagian kanan $\left(S_{4}\right.$ dan $\left.S_{5}\right)$ aktif dan menjalankan behavior mengikuti dinding kanan. Disisi lain percobaan pada Gambar 5.b, robot bergerak maju sampai mendeteksi dinding dan bernavigasi belok kanan. Selanjutnya robot mengikuti dinding kiri karena sensor bagian kiri $\left(\mathrm{S}_{1}\right.$ dan $\mathrm{S}_{2}$ ) aktif dan menjalankan behavior mengikuti dinding kiri. Behavior tersebut telah diimplementasikan metode LVQ dalam pengambilan keputusan untuk respon pergerakan robot, dan robot mampu bernavigasi dengan baik tanpa menabrak dinding.

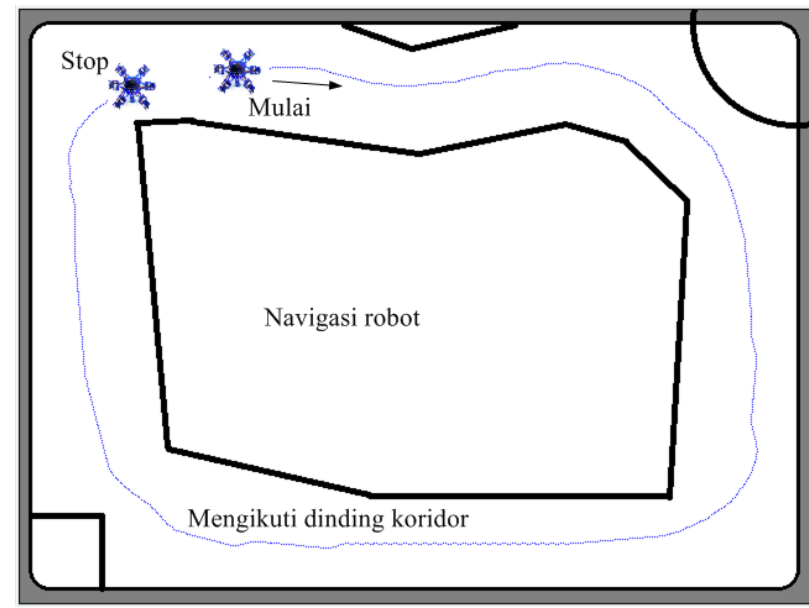

(a)

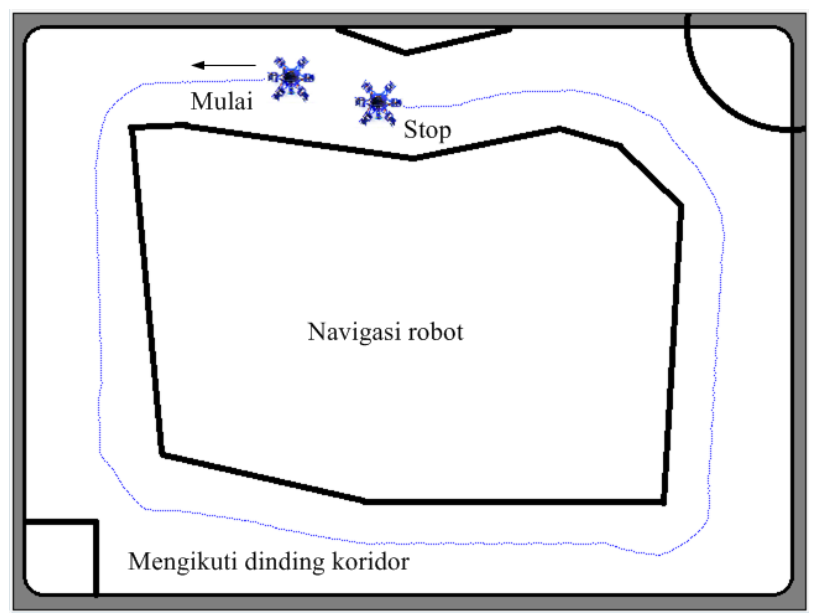

(b)

Gambar 6. Navigasi robot hexapod pada lingkungan koridor, (a) percobaan pada posisi 1, dan (b) posisi 2

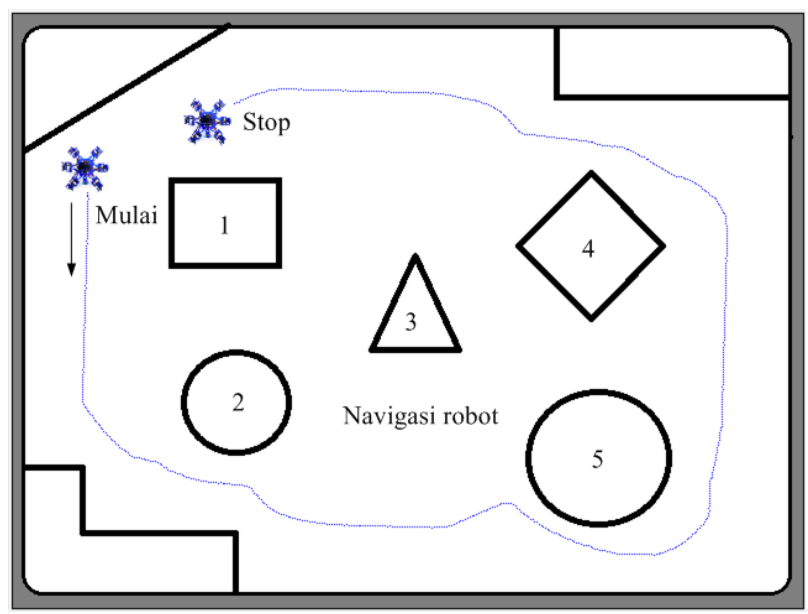

(a)

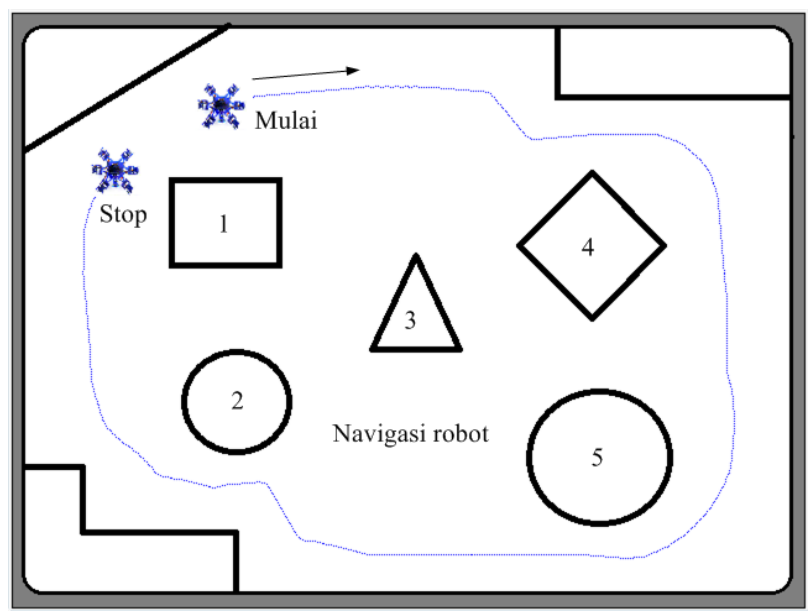

(b)

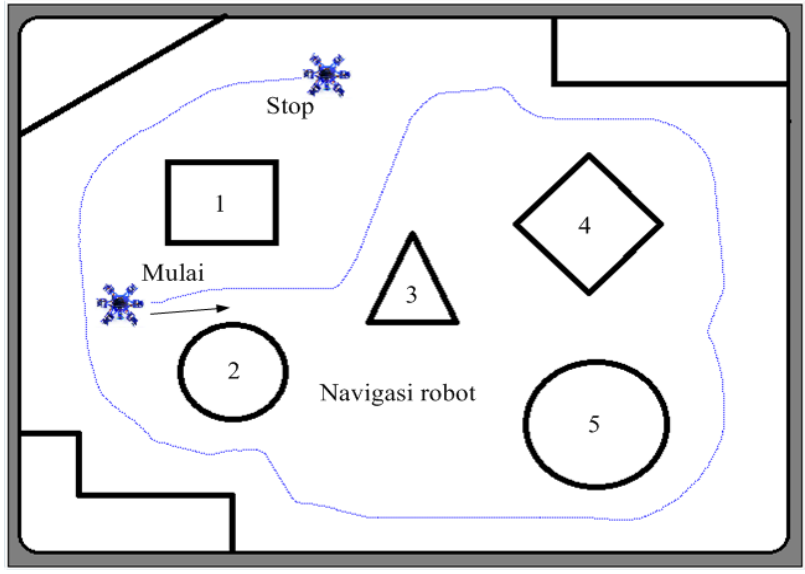

(c)

Gambar 7. Navigasi robot hexapod pada lingkungan kompleks, (a) percobaan pada posisi 1, (b) posisi 2, dan (c) posisi 3

B. Percobaan dalam lingkungan koridor

Pada percobaan ini robot ditempatkan pada lingkungan koridor. Percobaan ini dilakukan untuk mengetahui navigasi robot dalam lingkungan koridor. Gambar 6 menunjukkan navigasi robot hexapod ketika berada dalam lingkungan 
koridor. Percobaan ini dilakukan pada dua posisi. Pada posisi pertama (Gambar 6.a), robot dijalankan dan stimuli sensor kiri maupun kanan aktif secara bersamaan sehingga mengaktifkan behavior mengikuti jalur koridor. Selama proses bernavigasi mengikuti jalur koridor, akan terjadi kondisi dimana robot juga mengaktifkan behavior menghindar halangan jika sensor jarak $\left(\mathrm{S}_{3}\right)$ kurang dari 50 $\mathrm{cm}$. Hal ini terjadi pada saat robot melakukan aksi belok di setiap persimpangan, karena behavior menghindar halangan merupakan behavior dengan prioritas tertinggi. Begitu juga pada percobaan posisi kedua (Gambar 6.b), robot juga bernavigasi dengan mengikuti jalur koridor, dan juga terjadi kondisi mengaktifkan behavior menghindar halangan ketika sensor jarak $\left(\mathrm{S}_{3}\right)$ kurang dari $50 \mathrm{~cm}$. Dari percobaan tersebut robot bernavigasi dengan baik pada jalur koridor yang telah ditentukan dan tidak menabrak dinding.

\section{Percobaan dalam lingkungan kompleks}

Pada percobaan ini robot ditempatkan dalam lingkungan kompleks yang terdapat lima objek dengan bentuk dan ukuran yang berbeda pada posisi yang telah ditentukan. Gambar 7 menunjukkan navigasi robot hexapod di dalam lingkungan kompleks. Pada percobaan pertama (Gambar 7.a), robot ditempatkan pada samping dinding dan bernavigasi dengan behavior mengikuti dinding kanan karena stimuli dari sensor jarak $\mathrm{S}_{4}$ dan $\mathrm{S}_{5}$. Selanjutnya robot bernavigasi menghindar halangan untuk melalui objek 2, dan menghindari objek 5. Kemudian robot mengikuti dinding kanan sampai melalui objek 4 dan menuju serta melalui objek 1. Dalam bernavigasi di lingkungan ini robot tidak menabrak objek maupun dinding, dan robot dapat bernavigasi dengan baik. Pada percobaan kedua (Gambar 7.b), robot berada pada posisi yang berlawan dari percobaan sebelumnya, robot bernavigasi mengikuti dinding, menghindari objek 4, melalui objek 5, menghindari dan melalui objek 2 serta melalui objek 1 . Pada keadaan ini robot tidak menabrak objek ataupun dinding. Selanjutnya pada posisi ketiga (Gambar 7.c), robot bernavigasi melalui objek 1 dan objek 2, kemudian robot menghindari objek 3, melalui objek 4 dan objek 5, menghindari dan melalui objek 2 dan sampai melalui objek 1. Dalam percobaan ini robot juga dapat bernavigasi dengan baik dan tidak menabrak objek ataupun dinding. Dari ketiga percobaan tersebut dapat dikatakan bahwa robot berhasil bernavigasi di dalam lingkungan kompleks.

\section{KESIMPULAN}

Robot hexapod berbasis behavior dan metode LVQ telah berhasil dibuat dan di-implementasikan pada lingkungan yang telah ditentukan. Robot ini memiliki lima prilaku yaitu menghindar halangan (prioritas tertinggi), mengikuti jalur koridor, mengikuti dinding kiri, mengikuti dinding kanan, dan bergerak maju (prioritas terendah). Masing-masing behavior tersebut akan aktif jika mendapat stimuli nilai jarak berdasarkan ambang batas yang telah ditentukan. Adapun proses untuk manuver robot dalam masing-masing behavior dikontrol menggunakan LVQ. Berdasarkan dari hasil percobaan menunjukkan bahwa robot hexapod dapat bernavigasi dengan baik pada berbagai kondisi lingkungan tanpa menabrak objek ataupun dinding. Adapun pengembangan berikutnya yaitu implementasi mesin vision dalam aplikasi yang kompleks.

\section{UCAPAN TERIMA KASIH}

Terima kasih disampaikan kepada UPPM Fakultas Ilmu Komputer Universitas Sriwijaya yang telah memberikan dukungan dan dana dalam penelitian ini.

\section{Daftar Pustaka}

[1] A. A. A. Emhemed, Investigation in Two Wheels Mobile Robot Movement: Stability and Motion Paths, International Journal of Robotics and Automation (IJRA), vol. 2, no. 2, pp. 45-49, 2013.

[2] K. Joni, M. Ulum dan Z. Abidin, Robot Line Follower Berbasis Kendali Proportional-Integral-Derivative (PID) Untuk Lintasan Dengan Sudut Ekstrim, Jurnal Infotel, vol. 8, No. 2, pp. 138-142, 2016.

[3] M. A. Putra, B. Yudho dan P. Kurniasari, Pengendali Laju Kecepatan dan Sudut Steering Pada Mobile Robot Dengan Menggunakan Accelerometer Pada Smartphone Android, Mikrotiga, vol. 1, no. 2, pp. 19-24, 2014.

[4] H. Wicaksono, Prihastono, K. Anam, R. Effendi, I. A. Sulistijono, S. Kuswadi, A. jazidie, dan M. Sampei, Perancangan Sistem Navigasi Otonom Pada Behavior Based Hexapod Robot, Jurnal Teknik Elektro, vol. 8, no. 2, pp. 7078, 2008.

[5] Darwison dan R. Wahyudi, Kontrol Kecepatan Robot Hexapod Pemadam Api Menggunakan Metoda Logika Fuzzy, Jurnal Nasional Teknik Elektro, Vol. 4, No. 2, pp. 227-234, 2015.

[6] Y. R. Wahyudi, M. S. Hadi, A. n. Handayani dan S. Sendari, Implementasi Sistem Kendali PD (Proportional Derivative) Pada Navigasi Wall Follower Robot Berkaki Enam (Hexapod), $5^{\text {th }}$ Indonesian Symposium on Robotic Systems And Control, pp. 33-38, 2017.

[7] Rendyansyah, K. Exaudi, dan A. P. P. Prasetyo, Navigasi Berbasis Behavior Dan Fuzzy Logic Pada Simulasi Robot Bergerak Otonom, Jurnal Nasional Teknik Elektro, vol. 5, no. 1, pp. 135-144, 2016.

[8] A. Yulianto dan H. P. Handoyo, Penerapan Behavior-Based Control dan Fuzzy Logic Controller pada Sistem Navigasi Robot Soccer, CENTRE, Civil and Electrical Engineering Journal, vol. 7, no. 1, pp. 16-23, 2012.

[9] M. Gouko, C. H. Kim, dan Y. Kobayashi, Active Perception Model Extracting Object Features From Unlabeled Data, International Conference on Advanced Robotics (ICAR), pp. 518-523, 2017.

[10] Sutarno, R. F. Abdullah, R. Passarella. Identifikasi Tanaman Buah Berdasarkan Fitur Bentuk, Warna dan Tekstur Daun Berbasis Pengolahan Citra dan Learning Vector Quantization (LVQ), Prosiding Annual Research Seminar, vol. 3, No. 1, pp. 65-70, 2017.

[11] S. Kusumadewi, Artificial Intelligence (Teknik dan Aplikasinya), Penerbit Graha Ilmu, Yogyakarta, 2013. 